\title{
Faktor-Faktor yang Mempengaruhi Pengelolaan Keuangan Usaha Kecil Menengah dan Implikasinya terhadap Good Governance
}

\author{
Endar Pituringsih 1 \\ Fakultas Ekonomi dan Bisnis \\ Universitas Mataram, Indonesia
}

\author{
Thatok Asmony ${ }^{2}$ \\ Fakultas Ekonomi dan Bisnis \\ Universitas Mataram, Indonesia
}

\author{
Prayitno Basuki ${ }^{3}$ \\ Fakultas Ekonomi dan Bisnis \\ Universitas Mataram, Indonesia
}

\begin{abstract}
Surel : endar07ringsih@gmail.com
ABSTRAK

Penelitian bertujuan memperoleh bukti empiris mengenai pengaruh komitmen organisasi, sistem informasi akuntansi dan kapasitas sumber daya manusia terhadap pengelolaan keuangan Usaha Kecil Menengah (UKM) serta pengaruh pengelolaan keuangan UKM terhadap good governance. Penelitian dilakukan pada UKM di Kabupaten Lombok Barat. UKM yang ada di Kabupaten Lombok Barat berjumlah 120 yang tersebar di berbagai wilayah di Kabupaten Lombok Barat. Hasil penelitian menunjukan komitmen organisasi tidak berpengaruh secara signifikan terhadap pengelolaan keuangan. Teknologi informasi dan kompetensi SDM berpengaruh secara signifikan terhadap pengelolaan keuangan serta pengelolaan keuangan berpengaruh secara signifikan terhadap good governance.
\end{abstract}

Kata Kunci: Komitmen; Teknologi; Kompetensi; Pengelolaan Keuangan; Good Governance.

\section{Factors That Influence The Management Of Small Medium Enterprise And The Implication For The Implementation Of Good Governance}

\section{ABSTRACT}

The study aims to obtain empirical evidence about the influence of organizational commitment, accounting information systems and human resource capacity on Small Medium Enterprise (SME) financial management and the influence of SME financial management on good governance. The study was conducted on SMEs in West Lombok Regency. various regions in West Lombok Regency The results of the study indicate that organizational commitment does not significantly influence financial management Information technology and HR competencies significantly influence financial management and financial management significantly influence good governance.

Keywords: Commitment; Competent; Technology; Financial Management; Good Governance.

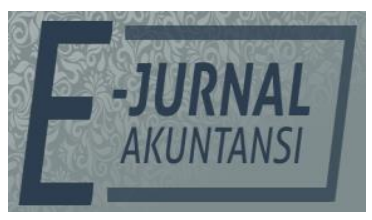

e-ISSN 2302-8556

Vol. 30 No. 8

Denpasar, Agustus 2020 Hal. 2152-2166

DOI:

10.24843/EJA.2020.v30.i08.p20

PENGUTIPAN:

Pituringsih, E., Asmony, T. \& Basuki, P. (2020). Faktor-Faktor yang Mempengaruhi

Pengelolaan Keuangan Usaha Kecil Menengah dan Implikasinya terhadap Good Governance. E-Jurnal Akuntansi, 30(8), 2152-2166

RIWAYAT ARTIKEL:

Artikel Masuk:

5 November 2019

Artikel Diterima: 23 Agustus 2020

Artikel dapat diakses : https://ojs.unud.ac.id/index.php/Akuntansi/index 


\section{PENDAHULUAN}

Usaha Kecil Menengah (UKM) merupakan salah satu penggerak perekonomian dalam suatu negara, UKM biasanya tumbuh dari industri keluarga, sehingga konsumennyapun berasal dari kalangan menengah ke bawah. Meskipun dilihat dari skala aktifitas ekonomi yang kecil namun jumlah UKM sangat besar dan dominan, sehingga dapat memberi kontribusi ekonomi baik untuk masyarakat maupun untuk negara. Peran UKM ini sendiri telah mendorong banyak negara, salah satunya Indonesia untuk terus berupaya dalam mengembangkan UKM. Salah satu pulau yang menjadi pusat pemerintah di Provinsi Nusa Tenggara Barat adalah Pulau Lombok. Lombok pusat pemerintahan sekaligus pusat perekonomian dimana UKM berkembang pesat menjadi penopang perekonomian masyarakat. Selain itu, UKM yang ada di Lombok Barat tersebar hampir di seluruh wilayah Kabupaten Lombok Barat.

Munculnya masalah dalam UKM seperti masalah permodalan, mengharuskan pemilik UKM untuk melakukan pengelolaan keuangan yang lebih baik. Pengelolaan keuangan tersebut dilakukan untuk mengatur keuangan yang dimiliki oleh UKM itu sendiri sehingga dapat memisahkan modal sendiri dan pendapatan yang diperoleh dari hasil usaha tersebut. Pengelolaan keuangan sangat ditentukan oleh sumber daya manusia yang terlibat di dalamnya. Apabila organisasi terbut mampu mengelola keuangan dengan baik maka kinerja organisasi tersebut dapat dikatakan baik pula.

Pengelolaan keuangan UKM terutama UKM yang ada di Kabupaten Lombok Barat akan dapat bertahan jika mampu mengelola keuangan. Terdapat beberapa faktor yang dapat mempengaruhi pengelolaan keuangan UKM diantaranya komitmen organisasi, teknologi informasi berbasis akuntansi, dan kapasitas sumber daya manusia. Oleh karena itu, agar pengelolaan keuangan UKM di Kabupaten Lombok Barat semakin baik, maka komponen-komponen tersebut harus ditingkatkan.

Komitmen organisasi merupakan tingkat sejauh mana seorang karyawan memihak pada suatu organisasi tertentu dan tujuan-tujuannya, serta berniat untuk mempertahankan keanggotaannya dalam organisasi itu. Apabila setiap pegawai memiliki komitmen yang kuat untuk memberikan prestasi terbaik baik masyarakat, maka tentunya kinerja sektor publik akan meningkat (Mahmudi, 2007). Penerapan teknologi informasi berbasis akuntansi berpengaruh dalam meningkatkan pengelolaan keuangan yang baik, karena sistem akuntansi perlu memanfaatkan semua jenis informasi dan teknologi komputer agar efektivitas dan efisiensi penyusunan laporan keuangannya dapat tercapai. Keberadaan sumber daya manusia yang mempunyai kompetensi sangat dibutuhkan didalam mewujudkan laporan keuangan yang berkualitas. Sumber daya manusia merupakan salah satu faktor yang menentukan keberhasilan suatu lembaga atau organisasi (Amran, 2009) dalam (Pramudiarta 2015). Kompetensi aparatur (SDM) adalah kemampuan yang harus dimiliki berupa pengetahuan, ketrampilan, sikap dan perilaku yang diperlukan dalam pelaksanaan tugasnya.

Sugeng (2014) melakukan penelitian dengan judul faktor-faktor yang mempengaruhi pengelolaan keuangan daerah dan implikasinya terhadap kinerja pemerintah daerah di Kabupaten Kediri. Hasil penelitian menunjukan bahwa kompetensi aparatur dan sistem informasi akuntansi tidak berpengaruh 
terhadap pengelolaan keuangan. Penelitian tersebut berbeda penelitian yang dilakuka oleh Ratifah \& Ridwan, (2012) yang menyatakan bahwa komitmen organisasi berpengaruh terhadap kualitas pengelolaan keuangan daerah.

Penelitian Ratifah \& Ridwan, (2012) menunjukan bahwa pengelolaan keuangan yang baik tidak akan berjalan dengan baik tanpa didukung oleh sistem akuntansi. Karena semakin baik sistem akuntansi maka akan semakin baik pengelolaan keuangan organisasi. Pernyataan ini juga didukung oleh (Nurillah \& Muid, 2014) yang meneliti tentang teknologi informasi akuntansi, dimana hasil penelitian menunjukan bahwa teknologi informasi akuntansi berpengaruh terhadap pengelolaan keuangan pada pemerintah daerah.

Rovenyanti (2011) melakukan penelitian terkait kompetensi SDM dalam mengelola keuangan daerah. Hasil penelitian menunjukan bahwa kompetensi berpengaruh dalam mengelola keuangan pemerintah. Hal ini disebabkan karena keterampilan SDM menentukan kualitas keuangan yang dikelola.

Berdasarkan latar belakang tersebut di atas, maka rumusan masalah dalam penelitian ini adalah 1) apakah komitmen organisasi, sistem informasi akuntansi dan kapasitas sumber daya manusia berpengaruh terhadap pengelolaan keuangan UKM?; 2) Apakah pengelolaan keuangan UKM berpengaruh terhadap good governance?

Berdasarkan rumusan masalah yang dikemukakan, tujuan penelitian ini adalah untuk memperoleh bukti empiris mengenai pengaruh komitmen organisasi, sistem informasi akuntansi dan kapasitas sumber daya manusia terhadap pengelolaan keuangan UKM serta pengaruh pengelolaan keuangan UKM terhadap good governance.

Secara sistematis rerangka konseptual penelitian ini dapat dilihat pada Gambar 1, sebagai berikut.

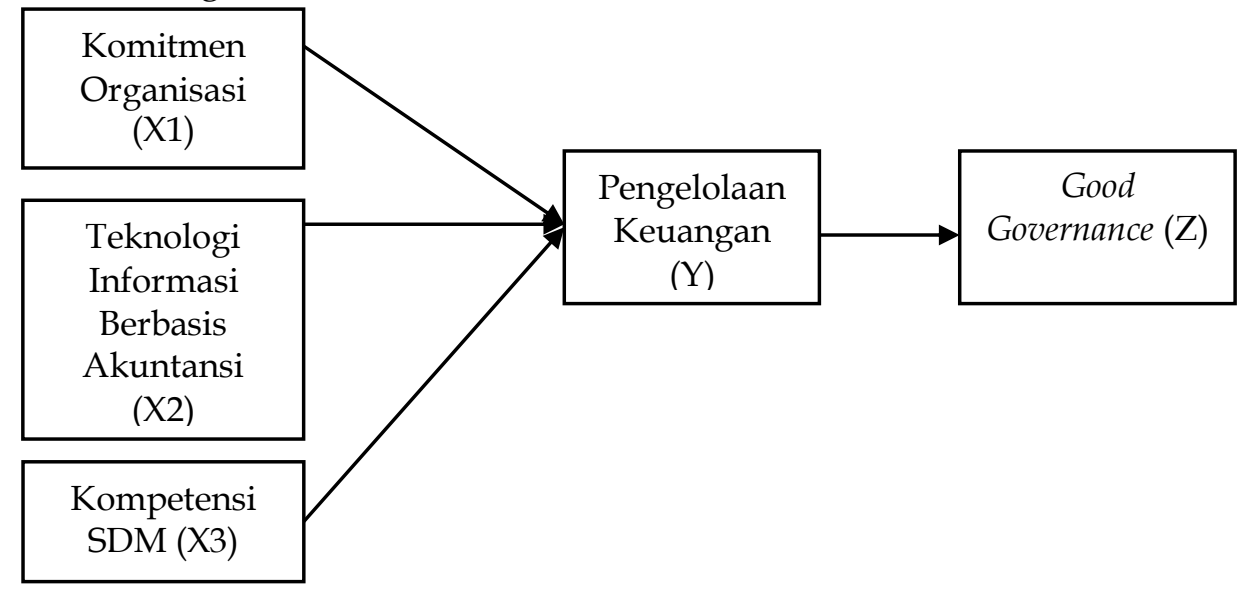

\section{Gambar 1. Model Penelitian}

Sumber : Data Penelitian, 2019

Komitmen organisasi menunjukkan suatu daya dari seseorang dalam mengidentifikasikan keterlibatannya dalam suatu bagian organisasi (Jayanti \& Binastuti, 2017). Karyawan yang memiliki komitmen organisasi tinggi akan lebih temotivasi untuk ikutserta dalam kegiatan dan tujuan organisasi (Mowdaw et all 1982). Oleh karena itu, komitmen organisasi akan menimbulkan rasa ikut memiliki (sense of belonging) bagi karyawan terhadap organisasi. Sehingga 
karyawan mempunyai tanggung jawab dan kesadaran dalam menjalankan organisasi sehingga menghasilkan pengelola keuangan yang lebih baik. Hal ini sesuai dengan penelitian Marlia Harahap, (2016), Sari et al., (2017) dan Astini et al., (2019) (Astini et al., 2019) bahwa komitmen organisasi komitmen organisasi memiliki pengaruh yang signifikan terhadap pengelolaan keuangan Pemerintah Daerah Kabupaten Lebong. Berdasarkan uraian, maka hipotesis yang dapat dibangun adalah sebagai berikut.

$\mathrm{H}_{1}$ : Komitmen organisasi berpengaruh terhadap pengelolaan keuangan UKM.

Davis et al. (1989) mendefinisikan persepsi atas kemanfaatan (perceived usefulness) sebagai tingkatan dimana seseorang percaya bahwa menggunakan sistem dapat meningkatkan kinerja. Pengelolaan keuangan dapat dikatakan berkualitas jika dalam penyusunan keuangan disajikan secara jujur, tepat, teliti dan dengan didukung oleh bukti-bukti yang jelas dan lengkap. Oleh karena itu sistem teknologi informasi berbasis akuntansi digunakan untuk mengurangi ketidaktelitian dan tingkat kesalahan para pengguna dalam mengelola keuangan. penggunaan teknologi informasi berbasis akuntansi dapat meningkatkan pengelolaan keuangan yang lebih baik. Sehingga good governance dapat tercapai. Penelitian Yosefrinaldi, (2013) memiliki hasil yang sama dengan studi (Nurillah \& Muid, 2014), dan Wijayanti, (2017) bahwa pemanfaatan teknologi informasi berpengaruh terhadap kualitas pengelolaan keuangan pemerintah daerah. Berdasar uraian, maka hipotesa pada penelitian ini adalah.

$\mathrm{H}_{2}$ : Teknologi informasi berbasis akuntansi berpengaruh terhadap pengelolaan keuangan UKM.

Sukmaningrum (2012), menyatakan bahwa kompetensi adalah pengetahuan dan keahlian yang diperlukan untuk menyelesaikan tugas. Kompetensi aparatur pemerintah berarti kemampuan yang harus dimiliki seorang aparatur berupa pengetahuan, keterampilan, sikap dan perilaku yang diperlukan dalam pelaksanaan tugasnya. Kompetensi SDM yang memadai dari segi kuantitas dan kualitas akan meningkatkan nilai informasi dalam pengelolaan keuangan. Wijayanti, (2017), melakukan penelitian mengenai pengaruh kompetensi sumber daya manusia terhadap kualitas pengelolaan keuangan daerah. Penelitian ini menyatakan bahwa kompetensi sumber daya manusia memberikan pengaruh yang signifikan terhadap kualitas pengelolaan keuangan pemerintah daerah. Hasil penelitian juga didukung oleh Nurillah \& Muid, (2014), Pujanira \& Taman, (2017), dan Simatupang (2017) yang menyatakan bahwa kompetensi SDM berpengaruh terhadap pengelolaan keuangan. Namun hasil Indriasari \& Nahartyo (2008), dan Zuliarti (2012) menyimpulkan bahwa SDM tidak berpengaruh terhadap nilai informasi dalam pengelolaan keuangan. Dengan demikian hipotesis yang dapat dibangun adalah sebagai berikut.

$\mathrm{H}_{3}$ : Kompetensi Sumber Daya Manusia berpengaruh terhadap pengelolaan keuangan UKM.

Pengelolaa keuangan adalah perencanaan, pengorganisasian dan pengendalian kegiatan keuangan seperti pengadaan dan pemanfaatan dana dari organisasi sehingga dapat mencapai tujuan organisasi secara efisien dan efektif. Apabila pengelolaan dapat dilakukan dengan baik, maka dapat dikatakan bahwa suatu organisasi memiliki tata kelola yang baik. Dimana organisasi tersebut 
mampu mengelola semua sumber daya yang digunakan untuk usaha dengan baik. Penelitian Sujana et al., (2014), Dhiyavani et al., (2017), dan Haura et al., (2019) menyatakan bahwa pengelolaan keuangan berpengaruh positif terhadap penerapan good govenance. Pengelolaan keuangan dapat membantu menciptakan good governance yang berkenaan dengan tata kelola dalam suatu organisasi terutama bagaimana anggaran dalam organisasi tersebut mempu di kelola dengan baik. Berdasarkan kajian teoritis dan hasil penelitian terdahulu maka hipotesis yang dapat dibangun pada penelitian ini adalah:

$\mathrm{H}_{4}$ : Pengelolaan keuangan UKM berpengaruh terhadap good governance.

\section{METODE PENELITIAN}

Jenis penelitian yang digunakan ini adalah kuantitatif dengan jenis asosiatif. yaitu merupakan penelitian yang bertujuan untuk mengetahui hubungan antara dua variabel atau lebih. Penelitian ini dilakukan pada UMKM di Kabupaten Lombok Barat. UMKM yang ada di Kabupaten Lombok Barat berjumlah 120, yang tersebar di berbagai wilayah di Kabupaten Lombok Barat. Seluruh populasi akan dijadikan sebagai responden dalam penelitian ini, sehingga penelitian ini disebut penelitian sensus.

Variabel eksogen dalam penelitian ini adalah Komitmen Organisasi (KO), Teknologi Informasi berbasis Akuntansi (TIA), dan Kompetensi Sumber Daya Manusia (KSDM). Indikator yang digunakan dalam variabel Komitmen Organisasi adalah organisasi memberi inspirasi mencapai prestasi, masalah organisasi adalah masalah saya, bertahan menjadi anggota organisasi adalah keinginan saya, keinginan membantu kesuksesan organisasi, organisasi memberi peluang meningkatkan kinerja organisasi, kepedulian kepada masa depan organisasi, bertahan menjadi anggota. Indikator variabel Teknologi Informasi berbasis Akuntansi adalah kemanfaatan dan kemudahan. Indikator yang dipakai untuk variabel Kompetensi Sumber Daya Manusia adalah pengetahuan, keahlian dan perilaku.

Variabel endogen yang digunakan dalam penelitian ini adalah Pengelolaan Keuangan (PK) dan Good Governance (GG). Menurut Halim (2007) indikator pengelolaan keuangan adalah perencanaan dan penganggaran keuangan, pelaksanaan dan penatausahaan, pertanggungjawaban keuangan dan pengawasan keuangan. Indikator yang digunakan untuk variabel good governance ini adalah akuntabilitas, transparansi, repsonsibilitas, independensi dan kesetaraan (Sanjaya, 2019). Indikator tersebut digunakan karena merupakan prinsip yang menjadi pilar utama dalam pelaksanaan good govenance. Kedua variabel endogen tersebut diukur dengan skala likert untuk mengukur sikap responden terhadap pernyataan yang diajukan.

Prosedur analisis data dalam penelitian ini terdiri dari analisis statistik deskriptif dan analisis Partial Least Square (PLS). Persamaan model pengukuran dalam penelitian ini adalah sebagai berikut.

$$
\begin{aligned}
& \mathrm{Y} 1=\beta 1 \mathrm{X} 1+\beta 2 \mathrm{X} 2+\beta 3 \mathrm{X} 3+\varepsilon . . \\
& \mathrm{Y} 2 \quad=\beta 4 \mathrm{Y} 1+\varepsilon \ldots \ldots \ldots \ldots \ldots \ldots \ldots \\
& \text { Keterangan }: \\
& \mathrm{Y} 1 \quad=\text { Pengelolaan Keuangan } \\
& \mathrm{Y} 2 \quad=\text { good governance }
\end{aligned}
$$




$$
\begin{array}{ll}
\mathrm{X} 1 & =\text { Komitmen Organisasi } \\
\mathrm{X} 2 & =\text { Teknologi Informasi } \\
\mathrm{X} 3 & =\text { Kompetensi SDM } \\
\varepsilon & =\text { error }
\end{array}
$$

\section{HASIL DAN PEMBAHASAN}

Data pada penelitian ini dikumpulkan dengan menyebarkan keusioner pada 120 UKM di Kabupaten Lombok Barat. Dari 120 kuesioner yang dibagikan, kuesioner yang kembali dan dapat diolah sejumlah $98(81,67 \%)$ kuesioner.

\begin{tabular}{|c|c|c|c|}
\hline No & Keterangan & Frekuensi & $\begin{array}{c}\text { Persentase } \\
(\%)\end{array}$ \\
\hline \multirow[t]{4}{*}{1} & Jenis Kelamin & & \\
\hline & Laki-laki & 66 & 67 \\
\hline & Perempuan & 32 & 33 \\
\hline & Jumlah & 98 & 100 \\
\hline \multirow[t]{6}{*}{2} & Usia & & \\
\hline & Di bawah 25 tahun & 27 & 28 \\
\hline & 25 - 35 tahun & 42 & 43 \\
\hline & $36-45$ tahun & 18 & 18 \\
\hline & Di atas 46 tahun & 11 & 11 \\
\hline & Jumlah & 98 & 100 \\
\hline \multirow[t]{7}{*}{3} & Tingkat Pendidikan & & \\
\hline & SLTP / Sederajat & 31 & 32 \\
\hline & SLTA / Sederajat & 55 & 56 \\
\hline & Diploma & 2 & 2 \\
\hline & S1 (Sarjana) & 9 & 9 \\
\hline & S2 (Pascasarjana) & 1 & 1 \\
\hline & Jumlah & 98 & 100 \\
\hline \multirow[t]{5}{*}{4} & Masa Kerja & & \\
\hline & $<5$ tahun & 58 & 59 \\
\hline & $5-10$ tahun & 23 & 24 \\
\hline & $\geq 11$ tahun & 17 & 17 \\
\hline & Jumlah & 98 & 100 \\
\hline
\end{tabular}
Karakteristik responden menggambarkan profil dari 98 responden yang berpartisipasi dalam pengisian kuesioner dapat dilihat pada Tabel 1.

\section{Tabel 1. Karakteristik Responden}

Sumber : Data Penelitian, 2019

Karakteristik responden berdasarkan jenis kelamin dapat digunakan untuk mengetahui responden laki-laki dan perempuan yang merupakan pebisnis UKM di Kabupaten Lombok Barat. Pada Tabel 1, menunjukkan bahwa jumlah responden laki-laki sebanyak 66 orang (67\%) dan jumlah responden perempuan sebanyak 32 orang (33\%). Dengan demikian dapat disimpulkan 
bahwa responden yang paling banyak bekerja sebagai pebisnis UKM di Kabupaten Lombok Barat adalah yang berjenis kelamin laki-laki.

Karakteristik responden berdasarkan usia dapat digunakan untuk mengetahui usia responden yang merupakan pebisnis UKM di Kabupaten Lombok Barat. Sebagian besar pebisnis UKM di Kabupaten Lombok Barat berusia 25 - 35 tahun. Artinya bahwa dengan usia seperti itu pebisnis UKM lebih mempunyai kreativitas, inovasi, tekun, ulet, dan gigih dalam menjalankan usahanya.

Karakteristik responden berdasarkan tingkat pendidikan dapat digunakan untuk mengetahui tingkat pendidikan responden yang merupakan pebisnis UKM di Kabupaten Lombok Barat. sebagian besar pebisnis UMKM di Kabupaten Lombok Barat berpendidikan terakhir SLTA / Sederajat, yaitu sebanyak 55 orang (56\%). Hal tersebut mengindikasikan bahwa pebisnis UMKM di Kabupaten Lombok Barat sebagian besar hanya berpendidikan terakhir SLTA, sehingga perlu ditingkatkan jenjang pendidikan para pelaku bisnis UMKM di Kabupaten Lombok Barat, agar pola berfikir dan cara pandang lebih kritis dan berinovasi.

Karakteristik responden berdasarkan masa kerja dapat digunakan untuk mengetahui masa kerja responden yang merupakan pebisnis UKM di Kabupaten Lombok Barat. sebagian besar pebisnis UMKM di Kabupaten Lombok Barat mempunyai masa kerja < 5 tahun (59\%). Hal tersebut mengindikasikan bahwa para pelaku bisnis UMKM di Kabupaten Lombok Barat, sebagian besar mempunyai masa kerja yang pendek, berarti responden selaku pelaku bisnis UMKM belum mampu mengembangkan usahanya dengan baik. Hasil uji reliabilitas dapat dilihat pada Tabel 2.

Tabel 2. Hasil Uji Reliabilitas

\begin{tabular}{lcc}
\hline \multicolumn{1}{c}{ Variabel } & Cronbach `s Alpha & Keterang \\
\hline Komitmen Organisasi (X1) & 0.877 & Reliabel \\
Sistem Informasi Berbasis Akuntansi & 0.857 & Reliabel \\
$(\mathrm{X} 2)$ & & \\
Kompetensi SDM (X3) & 0.859 & Reliabel \\
Pengelolaan Keuangan (Y1) & & Reliabel \\
& 0.837 & \\
Good Governance (Y2) & & Reliabel
\end{tabular}

Sumber : Data Penelitian, 2019

Berdasarkan Tabel 2, ditunjukan bahwa nilai cronbach's alpha dari masing-masing variabel lebih besar dari 0.6. Artinya pernyataan dalam kusisioner penelitian adalah reliabel dan dapat digunakan. Hasil uji validitas dapat dilihat pada Tabel 3. 
Tabel 3. Hasil uji validitas

\begin{tabular}{|c|c|c|c|c|}
\hline No & Variabel & Item/Pernyataan & $\begin{array}{l}\text { Pearson } \\
\text { Correlation }\end{array}$ & Keterangan \\
\hline \multirow[t]{7}{*}{1} & Komitmen & $\mathrm{X} 1.1$ & 0.770 & Valid \\
\hline & Organisasi & X1.2 & 0.770 & Valid \\
\hline & $(\mathrm{X} 1)$ & X1.3 & 0.616 & Valid \\
\hline & & X1.4 & 0.451 & Valid \\
\hline & & X1.5 & 0.430 & Valid \\
\hline & & X1.6 & 0.628 & Valid \\
\hline & & $\mathrm{X} 1.7$ & 0.737 & Valid \\
\hline \multirow[t]{5}{*}{2} & Sistem & X2.1 & 0.744 & Valid \\
\hline & Informasi & $\mathrm{X} 2.2$ & 0.739 & Valid \\
\hline & Berbasis & $\mathrm{X} 2.3$ & 0.820 & Valid \\
\hline & Akuntasni & $\mathrm{X} 2.4$ & 0.753 & Valid \\
\hline & $(\mathrm{X} 2)$ & $\mathrm{X} 2.5$ & 0.665 & Valid \\
\hline \multirow[t]{7}{*}{3} & Kompetensi & X3.1 & 0.623 & Valid \\
\hline & SDM & X3.2 & 0.735 & Valid \\
\hline & $(\mathrm{X} 3)$ & X3.3 & 0.728 & Valid \\
\hline & & X3.4 & 0.700 & Valid \\
\hline & & X3.5 & 0.800 & Valid \\
\hline & & X3.6 & 0.713 & Valid \\
\hline & & X3.7 & 0.618 & Valid \\
\hline \multirow[t]{3}{*}{4} & Pengelolaan & Y1.1 & 0.772 & Valid \\
\hline & Keuangan & Y1.2 & 0.863 & Valid \\
\hline & (Y1) & Y1.3 & 0.748 & Valid \\
\hline \multirow[t]{3}{*}{5} & Good Governance & Y2.1 & 0.828 & Valid \\
\hline & $(\mathrm{Y} 2)$ & Y2.2 & 0.782 & Valid \\
\hline & & Y2.3 & 0.759 & Valid \\
\hline
\end{tabular}

Sumber : Data Penelitian, 2019

Berdasarkan Tabel 3, disimpulkan bahwa instrumen dalam penelitian ini terdiri dari beberapa item pernyataan terkait komitem organisasi, sistem informasi berbasis akuntansi, kompetensi SDM, pengelolaan keuangan dan good governance menunjukan bahwa item-item pernyataan yang digunakan adalah valid karena nilai pearson correlation (positif) di atas nilai 0,30. Kuesioner dapat dikatakan valid apabila jawaban responden terhadap item pernyataan konsisten atau stabil dari waktu ke waktu.

Dalam penelitian ini nilai $\mathrm{R}^{2}$ digunakan untuk menjelaskan pengaruh variabel laten eksogen tertentu terhadap variabel endogen apakah mempunyai pengaruh yang subtantif. Kriteria nilai $\mathrm{R}^{2}$ yang digunakan untuk mengetahui seberapa baik model dalam penelitian ini jika $\mathrm{R}^{2}=0,75$ dapat disimpulkan kuat, $\mathrm{R}^{2}=0,50$ dapat disimpulkan moderat dan $\mathrm{R}^{2}=0,25$ dapat disimpulkan lemah. Nilai $\mathrm{R}^{2}$ yang diperoleh dari hasil evaluasi outer model disajikan pada Tabel 4.

Tabel 4. Nilai $\mathbf{R}^{2}$

\begin{tabular}{lll}
\hline \multicolumn{1}{c}{ Konstruk } & $\mathrm{R}^{2}$ & Kategori \\
\hline Pengelolaan Keuangan & 0,363 & Lemah \\
Good Governance & 0,073 & Lemah \\
\hline Sumber : Data Penenan
\end{tabular}

Sumber : Data Penelitian, 2019 
Berdasarkan Tabel 4, dapat disimpulkan bahwa konstruk endogen yaitu Pengelolaan Keuangan mampu dijelaskan oleh konstruk eksogen yaitu Komitmen Organisasi, ,Sistem Informasi berbasis Akuntansi dan Kompetensi SDM sebesar 36,3\%, sementara 63,7\% dijelaskan oleh faktor lain diluar model penelitian. Selanjutnya untuk konstruk endogen yaitu good governance mampu dijelaskan oleh konstruk endogen yaitu Pengelolaan Keuangan sebesar 7,3\%, sementara 92,7\% dijelaskan oleh faktor lain diluar model penelitian.

Goodness of fit diukur dengan menggunakan $\mathrm{Q}^{2}$ predictive relevance. Uji ini dilakukan untuk mengukur seberapa baik nilai observasi dihasilkan oleh model dan juga estimasi parameternya. Apabila dalam penelitian ini nilai $\mathrm{Q}^{2}>$ 0 , maka model mempunyai predictive relevance dan apabila nilai $\mathrm{Q}^{2}<0$, maka model kurang memiliki predictive relevance. Menurut Hussein (2015) untuk menghitung $\mathrm{Q}^{2}$ predictive relevance dapat digunakan rumus sebagai berikut:

$$
\begin{aligned}
& \mathrm{Q}^{2}=1-\left(1-\mathrm{R} 1^{2}\right)\left(1-\mathrm{R} 2^{2}\right) \\
& \mathrm{Q}^{2}=1-(1-0,363)(1-0,073) \\
& \mathrm{Q}^{2}=1-(0,637)(0,927) \\
& \mathrm{Q}^{2}=1-0,591 \\
& \mathrm{Q}^{2}=0,409
\end{aligned}
$$

Berdasarkan perhitungan di atas, dapat dijelaskan bahwa nilai $\mathrm{Q}^{2}$ sebesar 0,409 atau $\mathrm{Q}^{2}>0$, sehingga dapat disimpulkan bahwa model dalam penelitian ini mempunyai predictive relevance atau layak untuk menjelaskan variabel endogen yaitu Pengelolaan Keuangan dan good governance.

Setelah pengujian model struktural dilakukan, selanjutnya dilakukan uji hipotesis. Pengujian hipotesis penelitian ini menggunakan nilai t-statistik, maka untuk nilai alpha 5\% nilai t-tabel yang digunakan adalah 1,67 (Siregar, 2015:386). Kriteria penerimaan hipotesa adalah ketika t-statistik > t-tabel (Hussein, 2015). Nilai t-statistik yang diperoleh dari nilai path coefficient disajikan pada Tabel 5.

Tabel 5. Nilai Path Coefficient

\begin{tabular}{llllll}
\hline Variabel & $\begin{array}{l}\text { Original } \\
\text { Sample }\end{array}$ & $\begin{array}{l}\mathrm{T} \\
\text { Statistic }\end{array}$ & $\begin{array}{l}\mathrm{P} \\
\text { Values }\end{array}$ & Keterangan & Keputusan \\
\hline KO -> PK & 0,129 & 0,632 & 0,264 & $\begin{array}{l}\text { Tidak } \\
\text { Signifikan }\end{array}$ & $\begin{array}{l}\text { Hipotesis } \\
\text { ditolak }\end{array}$ \\
TIA -> PK & 0,327 & 1,821 & 0,035 & Signifikan & $\begin{array}{l}\text { Hipotesis } \\
\text { diterima }\end{array}$ \\
$\begin{array}{l}\text { KSDM -> } \\
\text { PK }\end{array}$ & 0,275 & 4,061 & 0,000 & Signifikan & $\begin{array}{l}\text { Hipotesis } \\
\text { diterima }\end{array}$ \\
PK -> GG & 0,271 & 3,207 & 0,001 & Signifikan & $\begin{array}{l}\text { Hipotesis } \\
\text { diterima }\end{array}$ \\
\hline
\end{tabular}

Sumber : Data Penelitian, 2019

Persamaan model struktural (inner model) adalah sebagai berikut :

$\mathrm{PK}=0,129 \mathrm{KO}+0,327 \mathrm{KSDM}+0,275 \mathrm{SIA}+\zeta_{1}$

$\mathrm{GG}=0,271 \mathrm{PK}+\zeta_{2}$

Komitmen organisasional merupakan sikap yang menunjukkan "loyalitas" karyawan dan merupakan proses berkelanjutan bagaimana seorang anggota organisasi mengekspresikan perhatian mereka kepada kesuksesan dan kebaikan organisasinya (Luthans, 2006) dalam (Manullang, 2009:69). Seseorang 
yang bergabung dalam organisasi pada sebuah perusahaan dituntut adanya komitmen dalam dirinya. Pegawai atau karyawan dengan komitmen yang tinggi dapat diharapkan akan memperlihatkan kinerja yang optimal. Komitmen organisasi juga mencakup keterlibatan kerja. Hal ini disebabkan karena antara keterlibatan kerja dengan komitmen organisasi sangat erat hubungannya. Keterlibatan kerja sebagai derajat kemauan untuk menyatukan dirinya dengan pekerjaan, menginvestasikan waktu, kemampuan dan energinya untuk pekerjaan, dan menganggap pekerjaannya sebagai bagian utama dari kehidupannya.

Hasil pengujian statistik diperoleh nilai t-statistik sebesar 0,632, lebih kecil dari t-tabel $(1,66)$ pada level signifikansi 5 persen dan nilai signifikansi yang diperoleh sebesar 0,264, lebih besar dibandingkan nilai alpha 0,05 sehingga dapat disimpulkan bahwa hipotesis pertama yang menyatakan bahwa komitmen organisasi berpengaruh terhadap pengelolaan keuangan UKM ditolak. Nilai koefisien parameter komitmen organisasi terhadap pengelolaan keuangan UKM sebesar 0,129 dengan arah positif. Artinya komitmen organisasi berpengaruh positif terhadap pengelolaan keuangan UKM namun tidak signifikan.

Komitmen organisasi akan menimbulkan rasa ikut memiliki (sense of belonging) bagi karyawan terhadap organisasi. Sehingga karyawan mempunyai tanggung jawab dan kesadaran dalam menjalankan organisasi sehingga menghasilkan pengelola keuangan yang lebih baik. Akan tetapi hasil penelitian ini menemukan bahwa komitmen organisasi tidak berpengaruh secara signifikan terhadap pengelolaan keuangan UKM. Hal ini disebabkan karena walaupun UKM memiliki suatu kebijakan dan peraturan terkait pengelolaan keuangan akan tetapi tidak selamanya dapat dijalankan dengan baik oleh pelaku UKM. Oleh karena itu, dalam meningkatkan pengelolaan keuangan UKM perlu ditingkatkan pula komitmen pelaku UKM dalam mengelola keuangan organisasi. Komitmen menggambarkan loyalitas, ketertarikan, keterlibatan anggota organisasi dalam melakukan tugas tanggung jawabnya sesuai dengan peraturan yang berlaku.

Teknologi informasi dapat diartikan sebagai suatu teknologi yang digunakan untuk mengolah data, termasuk memproses, mendapatkan, menyususn, menyimpan, memanipulasi data dalam berbagai cara untuk menghasilkan informasi yang berkaulitas, yaitu informasi yang relevan, akurat dan tepat waktu, yang digunakan untuk keperluan pribadi, bisnis, dan pemerintahan dan merupakan informasi yang strategis untuk pengambilan keputusan. Pengelolaan data dengan memanfaatkan teknologi informasi (komputer dan jaringan) akan memberikan banyak keunggulan baik dari sisi keakuratan/ketepatan hasil operasi maupun sebagai mesin multiguna, multiprocessing. Pemanfaatan teknologi informasi juga akan mengurangi kesalahan yang terjadi.

Hasil pengujian statistik diperoleh nilai t-statistik sebesar 1,821, lebih besar dari t-tabel $(1,66)$ pada level signifikansi 5 persen dan nilai signifikansi yang diperoleh sebesar 0,035, lebih kecil dibandingkan nilai alpha 0,05 sehingga dapat disimpulkan bahwa hipotesis kedua yang menyatakan bahwa teknologi informasi berbasis akuntansi berpengaruh terhadap pengelolaan 
keuangan UKM diterima. Nilai koefisien parameter teknologi informasi berbasis akuntansi terhadap pengelolaan keuangan UKM sebesar 0,327 dengan arah positif. Artinya teknologi informasi berbasis akuntansi berpengaruh positif dan signifikan terhadap pengelolaan keuangan UKM.

Untuk mempertahankan kelangsungan hidup suatu organisasi, dibutuhkan penyesuaian dengan lingkungan usaha yang terus berubah. Hal ini juga berlaku bagi UKM. UKM harus menyesuaikan dengan perubahan lingkungan usaha, salah satunya adalah perubahan teknologi informasi. Kehadiran teknologi informasi memberikan banyak manfaat bagi UKM, seperti mampu meringankan aktivitas bisnis yang kompleks serta menghasilkan informasi yang dapat dipercaya, relevan, tepat waktu, lengkap, dapat dipahami, dan teruji dalam pengelolaan keuangan. Selain itu, efisiensi operasi UKM dan kinerja UKM juga akan dapat ditingkatkan. Sehingga UKM dapat bertahan dalam era informasi serta mampu menghadapi persaingan usaha.

Hipotesis ketiga yang menyatakan bahwa kompetensi SDM berpengaruh terhadap pengelolaan keuangan. Tabel 5, menunjukan nilai tstatistik untuk pengaruh kompetensi SDM terhadap pengelolaan keuangan adalah 4,061. Nilai ini lebih besar dibandingkan $t$ tabel level signifikasni 0,05 yaitu 1,660, sehingga dapat disimpulkan bahwa hipotesis diterima. P value untuk pengaruh kompetensi SDM terhadap pengelolaan keuangan sebesar 0,000 lebih kecil dari 0,05 dengan nilai koefisien sebesar 0,275, artinya hipotesis ketiga diterima. Kompetensi merupakan kemampuan yang harus dimiliki seseorang berupa pengetahuan, keterampilan, sikap dan perilaku yang diperlukan dalam pelaksanaan tugasnya. Kompetensi SDM yang memadai dari segi kuantitas dan kualitas akan meningkatkan nilai informasi dalam pengelolaan keuangan. Dengan demikian, jika kompetensi SDM bagian keuangan/akuntansi pada UKM Kabupaten Lombok Barat baik, dalam artian SDM keuangan/akuntansi tersebut kompeten, maka pengelolaan keuangan yang dihasilkan UKM pada Kabupaten Lombok Barat lebih baik. Hal tersebut juga didukung oleh keterampilan, pengetahuan, dan kemampuan yang dimiliki oleh responden dalam membuat mengelola keuangan. Selain itu pengalaman kerja, kemampuan kerja dan pelatihan yang dimiliki bisa mempengaruhi kompetensi sumber daya manusia.

Hasil penelitian ini sejalan dengan Rovieyanti (2011), Yosefrinaldi, (2013) dan Nurillah \& Muid, (2014) yang melakukan penelitian mengenai pengaruh kompetensi sumber daya manusia terhadap kualitas pengelolaan keuangan daerah. Penelitian ini memberikan hasil bahwa kompetensi sumber daya manusia memberikan pengaruh yang signifikan terhadap kualitas dalam mengelola keuangan pemerintah. Dilihat dari distribusi frekuensi, bahwa kompetensi SDM memiliki pengaruh terhadap pengelolaan keuangan UKM. Hal ini dapat dibuktikan dari jawaban responden terhadap kuisioner yang disebarkan. Secara garis besar kompetensi SDM pada UKM Kabupaten Lombok Barat sudah baik.

Hipotesis keempat yang menyatakan bahwa pengelolaan keuangan berpengaruh terhadap good governance. Tabel 5, menunjukan nilai t-statistik untuk pengaruh pengelolaan keuangan terhadap good governance adalah 3,207 adalah. Nilai ini lebih besar dibandingkan t tabel level signifikasni 0,05 yaitu 
1,660, sehingga dapat disimpulkan bahwa hipotesis diterima. $\mathrm{P}$ value untuk pengaruh pengelolaan keuangan terhadap good governance 0,001 lebih kecil dari 0,05 dengan nilai koefisien sebesar 0,271, artinya hipotesis keempat diterima. Dimana semakin baik pengelolaan keuangan daerah, maka good governance pun akan tercapai dengan baik pula. Hasil penelitian sejalan dengan penelitian Ristanti (2014) dan Ruspina (2013) yang menyatakan bahwa pengelolaan keuangan berpengaruh positif terhadap good governance. Pengelolaa keuangan adalah perencanaan, pengorganisasian dan pengendalian kegiatan keuangan seperti pengadaan dan pemanfaatan dana dari organisasi sehingga dapat mencapai tujuan organisasi secara efisien dan efektif. Apabila pengelolaan dapat dilakukan dengan baik, maka dapat dikatakan bahwa suatu organisasi memiliki tata kelola yang baik. Dimana organisasi tersebut mampu mengelola semua sumber daya yang digunakan untuk usaha dengan baik.

Hubungan sistem pengelolaan keuangan untuk menciptakan good governance dilihat pada perspektif sistem dan pengakuan akuntansi dan anggaran melalui tiga tahapan yaitu : tahap perencanaan, pelaksanaan dan pengendalian yaitu masing-masing tahap meliputi input, proses dan output yang sudah ditetapkan kemudian dilaksanakan menggunakan sistem akuntansi yang sudah disesuaikan untuk menghasilkan informasi yang berguna baggi semua pihak yang berkepentingan. Tahap pengendalian inputnya berupa laporan keuangan yang kemudian diproses sebagai dasar evaluasi terhadap laporan tersebut sekaligus dapat digunakan sebagai penilaian pertanggungjawaban. Dengan demikian pengelolaan keuangan berpengaruh positif terhadap penerapann good governance UKM di Kabupaten Lombok Barat. Hal ini juga dapat dilihat dari distribusi frekuensi, bahwa pengelolaan keuangan memiliki pengaruh terhadap good governance, dengan dibuktikan dari jawaban responden yang secara garis besar pengelolaan keuangan pada UKM Kabupaten Lombok Barat sudah sangat baik.

\section{SIMPULAN}

Dari hasil penelitian yang dilakukan, beberapa simpulan yang dapat diambil antara lain : 1) Penelitian ini memberikan bukti empiris bahwa komitmen organisasi tidak berpengaruh terhadap pengelolaan keuangan UKM Kabupaten Barat. Hal ini menunjukkan bahwa komitmen organisasi tidak meningkatkan pengelolaan keuangan UKM Kabupaten Lombok Barat. 2) Penelitian ini memberikan bukti empiris bahwa sistem informasi berbasis akuntansi berpengaruh secara signifikan terhadap pengelolaan keuangan UKM Kabupaten Lombok Barat. Sistem informasi berbasis akuntansi yang baik akan meningkatkan pengelolaan keuangan. Hal tersebut dikarenakan kemudahan dan efektif dalam mengelola keuangan UKM. Semakin tinggi system infromasi berbasis akuntansi maka semakin baik pengelolaan keuangan UKM di Kabupaten Lombok Barat. 3) Penelitian ini memberikan bukti empiris bahwa kompetensi SDM berpengaruh secara signifikan terhadap pengelolaan keuangan UKM di Kabupaten Lombok Barat. Hal ini disebabkan karena kompetensi SDM dapat meningkatkan pengelolaan keuangan dengan cara diberikan pelatihan secara terus menerus sehingga anggota UKM akan lebih mudah dalam mengelola keuangan UKM. 4) Penelitian ini memberikan bukti empiris bahwa 
pengelolaan keuangan berpengaruh secara signifikan terhadap good governance UKM di Kabupaten Lombok Barat. Hal ini disebabkan karena pengelolaan keuangan yang baik berarti telah memiliki tata kelola yang baik dalam organisasi. Artinya organisasi mampu mengelola semua sumber daya yang digunakan untuk usaha dengan baik.

Dari hasil penelitian yang dilakukan, beberapa saran yang dapat disampaikan sebagai berikut :1) UKM di Kabupaten Loombok Barat perlu meningkatkan komitmen organisasi sehingga kepentingan organisasi dapat terwujud untuk meningkatkan sistem pemerintah yang lebih baik. 2) Penelian ini dapat dikembangkan dengan sampel yang lebih banyak lagi tidak hanya UKM di Kabupaten Lombok Barat sehingga kemampuan generalisasinya untuk memperlihatkan pengeloaan keuangan dan good governance menjadi kuat. 3) Hasil penelitian ini dapat memberikan masukan bagi peneliti berikutnya yang ingin meneliti tentang pengelolaan keuangan dan good governance dan disarankan untuk menambah variabel lain yang mempengaruhi pengelolaan keuangan seperti kinerja organisasi dan sistem pengendalian internal.

\section{REFERENSI}

Astini, Y., Fauzi, A. K., \& Widowati. (2019). Determinan yang Mempengaruhi Keberhasilan Pengelolaan Keuangan Desa. Jurnal Ilmiah Valid.

Abdillah, Willy dan Jogiyanto, (2015). Partial Least Square, Alternatif Structural Equation Modeling (SEM) dalam Penelitian Bisnis. Penerbit ANDI. Yogyakarta.

Andriani, Wiwik. (2010). Pengaruh Kapasitas Sumber Daya Manusia dan Pemanfaatan Teknologi Informasi Terhadap Keterandalan dan Ketepatwaktuan Laporan Keuangan Pemerintah Daerah( Studi Pada Pemerintah Daerah Kab. Pesisir Selatan ). Jurnal Akuntansi dan Manajemen, Vol 5 No.1 Juni 2010 ISSN 1858-3687 hal 69-80.

Arsiningsih, Ni Luh Putu Febri. (2015). Pengaruh Penggunaan Teknologi Informasi, Efektivitas Sistem Informasi Akuntansi, Kepercayaan Atas Sistem Informasi Akuntansi, Sistem Pengendalian Intern Terhadap Kinerja Karyawan Pada Bank Perkreditan Rakyat di Kabupaten Buleleng dan Bangli. Jurusan Akuntansi Volume 3 Nomor 1.

Azlim, Darwanis dan Usman Abu Bakar, (2012). Pengaruh Penerapan good Governance Dan Standar Akuntansi Pemerintah Terhadap Kualitas Informasi Keuangan SKPD di Kota Banda Aceh. Jurnal Akuntansi Pascasarjana Universitas Syiah Kuala. ISSN 2302-0164.

Batubara, A. H., (2006). Konsep Good Governance Dalam Konsep Otonommi Daerah.Jurnal Analisis Administrasi dan Kebijakan. Vol. 3, No. 1.

Dhiyavani, S., Nasir, A., \& Paulus, S. (2017). Pengaruh Kinerja Aparatur Pemerintah Daerah, Pengelolaan Keuangan Daerah, Sistem Pengendalian Internal, dan Implementasi Standar Akuntansi Pemerintah terhadap Penerapan Good Governance. Jurnal Online Mahasiswa Fakultas Ekonomi Universitas Riau.

Effendi, Sofian., (2011). Langkah Menuju Perwujudan Good Governance dan Peningkatan Kualitas Laporan Keuangan Pemerintah Pusat. Rakernas Akuntansi 2011. 
Jayanti, L. D., \& Binastuti, S. (2017). Pengaruh Intellectual Capital Terhadap Nilai Perusahaan Dengan Kinerja Keuangan Sebagai Variabel Intervening. Jurnal Ekonomi Bisnis.

Marlia Harahap, A. (2016). Pengaruh Tingkat Pendidikan, Pengalaman Kerja, Gaji dan Komitmen Organisasi Terhadap Kinerja Pengelola Keuangan Pemerintah Daerah Kabupaten Lebong. E-Mabis: Jurnal Ekonomi Manajemen Dan Bisnis. https:// doi.org/10.29103/e-mabis.v17i1.54

Nurillah, A. S., \& Muid, D. (2014). Pengaruh Kompetensi SDM, Penerapan SAKD, Pemanfaatan Teknologi Informasi dan Sistem Pengendalian Intern Terhadap Kualitas Laporan Keuangan Pemerintah Daerah. E- Joural Akuntansi UNDIP.

Handoko, T.H. (2001). Manajemen Personalia dan Sumber Daya Manusia. Jakarta : PT. Gramedi.

Harahap, Marliah., Abdullah. (2016). Pengaruh Tingkat Pendidikan, Pengalaman Kerja, Gaji dan Komitmen Organisasi Terhadap Pengelolaa Keuangan Pemerintah Daerah Kabupaten Lebong. Journal Of Economic Management \& Business. Vol 17 No 1 : 9-26.

Haura, G.A., Afrah, Junita., Tuti. M. (2019). Pengaruh Sistem Pengendalian Internal Pemerintah, Pengelolaan Keuangan Daerah, Dan Kinerja Aparatur Pemerintah Daerah Terhadap Good Governance Dengan Komitmen Organisasi Sebagai Variabel Moderasi (Studi Pada SKPK Kota Langsa). Universitas Samudra. Jurnal Penelitian Ekonomi Akuntansi Vol 3 No 1: 3352.

Indriasari, Desi \& Ertambang Nahartyo (2008). Pengaruh Kapasitas Sumber Daya Manusia, Pemanfaatan Teknologi Informasi dan Pengendalian Intern Akuntansi terhadap Nilai Informasi Pelaporan Keuangan Pemerintah Daerah (Studi pada Pemerintah Kota Palembang dan Kabuppaten Ogan Hilir). Simposium NasionalAkuntasi XI, Politeknik Negeri Sriwijaya, Palembang.

Indra Bastian. (2006) . Akuntansi sektor publik suatupengantar. Jakarta: Erlangga .

Karmila, Tanjung A.R, dan Darlis, Edfan. (2013). Pengaruh Kapasitas Sumber Daya Manusia, Pemanfaatan Teknologi Informasi, Dan Pengendalian Intern Terhadap Keterandalan Pelaporan Keuangan Pemerintah Daerah (Studi Pada Pemerintah Provinsi Riau).Jurnal SOROTVol 9 No 1 April Lembaga Penelitian Universitas Riau ISSN 1907 - 364X, 25 - 42.

Kuncoro, Mudrajat. (2003). Metode Riset UntukBisnis dan Ekonomi. Jakarta: Erlangga.

Latan, Hengky., dan Ghozali , Imam. (2012). Partial Lest Square, Konsep, Teknik dan Aplikasi SMARTPLS 2.0 M3 Untuk Penelitian Bisnis. Badan Penerbit UNDIP. Semarang.

Malthis, Robert L. and Jackson John H. (2006). Manajemen Sumber Daya Manusia Edisi Kesepuluh. Jakarta: Salemba Empat.

Nurillah, A.S., Muid, Dul., (2014). Pengaruh Kompetensi Sumber Daya Manusia, Penerapan Sistem Akuntansi Keuangan Daerah (SAKD), PemanfaatanTeknologi Informasi dan Sistem Pengendalian Intern Terhadap Kualitas Laporan Keuangan Pemerintah Daerah. Diponegoro Journal of Accounting Volume 3 Nomor 2 Tahun 2014 Halaman 200-212 ISSN (online) 2337-3806. 
Pujanira, P., \& Taman, A. (2017). Penerapan Sistem Akuntansi Keuangan Daerah terhadap Kualitas Laporan Keuangan Pemerintah Daerah Provinsi DIY. Jurnal Nominal. https://doi.org/10.21831/nominal.v6i2.16643

Ratifah, I., \& Ridwan, M. (2012). Komitmen Organisasi Memoderasi Pengaruh Sistem Akuntansi Keuangan Daerah terhadap Kualitas Laporan Keuangan. Trikonomika.

Sugeng. (2014). Faktor-Faktor Yang Mempengaruhi Pengelolaan Keuangan Daerah Dan Implikasinya Terhadap Kinerja Pemerintah Daerah Kabupaten Kerinci. Jurnal Riset Ekonomi dan Bisnis, Vol 1 No 2 : 16-26.

Tri, Dani Danuar. (2013). Pengembangan Usaha Mikro Kecil dan Menengah (UMKM) Berbasis Ekonomi Kreatif Di Kota Semarang. Semarang: Fakultas Ekonomi dan Bisnis Universitas Diponegoro.

Wijayanti, R. (2017). Pengaruh kompetensi sdm dan implementasi akuntansi akrual terhadap kualitas laporan keuangan daerah. Jurnal Ilmu Dan Riset Akuntansi Volume 6,Nomor 3,Maret 2017.

Yosefrinaldi. (2013). Pengaruh Kapasitas Sumber Daya Manusia Dan Pemanfaatan Teknologi Informasi Terhadap Kualitas Laporan Keuangan Pemerintah Daerah Dengan Variabel Intervening Sistem Pengendalian Intern Pemerintah (Studi Empiris Pada DPKAD Se-Sumatera Barat). Jurnal Akuntansi.

Zuliarti. (2012). Pengaruh Kompetensi Jabatan Penatausahaan Keuangan, Sistem Pengendalian Intern, Dan Pengawasan Keuuangan Daerah Terhadap Nilai Informasi Laporan Keuangan Pemerintah Daerah. Universitas Padang. 